\title{
PENINGKATAN KEMAMPUAN MENYUSUN TEKS EKSPLANASI MELALUI PEMBELAJARAN KONTEKSTUAL DENGAN MEDIA AUDIO-VISUAL PADA SISWA KELAS VII F SMP WISATA SANUR TAHUN PELAJARAN 2017/ 2018
}

\author{
Reginaldis Fitriani Elsa, I Nyoman Suparsa dan Ni Ketut Pola Rustini \\ Program Studi Pendidikan Bahasa dan Sastra Indonesia \\ Fakultas Keguruan dan Ilmu Pendidikan \\ Universitas Mahasaraswati Denpasar
}

\begin{abstract}
ABSTRAK
Penelitian ini menggunakan jenis penelitian tindakan kelas (PTK). Subjek penelitian adalah siswa kelas VII F SMP Wisata Sanur yang berjumlah 42 orang siswa. Objek penelitian adalah penerapan pembelajaran kontekstual dengan media audio-visual untuk meningkatkan kemampuan menyusun teks eksplanasi. Rancangan penelitian tindakan kelas ini, dilaksanakan secara bertahap atau multi siklus hingga dicapai hasil sesuai dengan target yang diinginkan. Pengumpulan data dilakukan dengan menggunakan metode observasi dan metode tes dalam bentuk tugas mengarang. Metode observasi dilakukan untuk mengumpulkan data yang berkenaan dengan sikap, dan aktivitas siswa dalam proses pembelajaran. Tes tulis dalam bentuk tugas mengarang dengan jumlah soal 1 butir dengan 5 aspek penilaian dan rentang skor 1-20 dengan jumlah skor ideal seluruhnya adalah 100 . Hasil tes yang diperoleh dalam penerapan pembelajaran kontekstual denganmediaaudiovisual untuk Meningkatkan Kemampuan Menyusun Teks Eksplanasi Siswa Kelas VII F SMP Wisata Sanur Tahun Pelajaran 2017/ 2018 mengalami peningkatan. Pada tes awal nilai rata--rata hanya 4,07 dengan kategori kurang, Siklus I nilai rata--rata 5,30 dengan kategori hampir cukup, Siklus II nilai rata--rata 6,92 dengan kategori lebih dari cukup dan nilai ratarata siswa pada Siklus III mengalami peningkatan menjadi 8,40 dengan kategori baik sekali. Berdasarkan hasil tes tersebut dapat disimpulkan bahwa pembelajaran kontekstual dengan media audio-visual dapat meningkatkan kemampuan menyusun teks eksplanasi pada siswa kelas VII F SMP Wisata Sanur Tahun Pelajaran 2017/2018.
\end{abstract}

Kata Kunci :Teks Eksplanasi, Pembelajaran Kontekstual, Media Audio-Visual

\section{ABSTRACT}

This study uses classroom action research (CAR). The subjects were students of class VII F SMP Wisata Sanur totaling 42 students. The object of research is the application of contextual learning with audio-visual media to enhance the ability of preparing explanatory text. The design of this class action research, carried out in stages or multiple cycles until results are achieved in accordance with the desired target. The data collection is done by using the method of observation and testing methods in the form of duty fabricated. Observation methods used to collect the data pertaining to attitudes and activities of students in the learning process. Written test in the form of duty fabricated by the amount of about 1 point with 5 aspects of assessment and score range 1-20 with a number of wholly ideal score is 100. The test results obtained in the application of contextual learning with media audio-visual to Enhance Capabilities Develop explanatory text F Grade VII SMP Wisata Sanur Academic Year 2017/2018 has increased. In the initial test value - average only 4.07 with less category, the first cycle value - average of 5.30 with a category is almost 
enough, the second cycle value - average of 6.92 with more than enough categories and average value Cycle III students on the average increased to 8.40 with a good category. Based on the results of the tests can be concluded that contextual learning with audio-visual media can improve the ability compile explanatory text in class VII F SMP Wisata Sanur in academic year2017/2018.

Keywords: Text explanation, Contextual Learning, Media Audio - Visual

\section{PENDAHULUAN}

Bahasa merupakan alat komunikasi yang penting dalam kehidupan seharihari. Bahasa Indonesia sangat penting perannya bagikehidupan bermasyarakat,berbangsa, dan bernegara. Semakin terampil seseorang berbahasa, semakin cerah dan jelasjalan pikirannya (Tarigan, 2008:1).

Keterampilan berbahasa mempunyai empatkomponen, di antaranya: keterampilan menyimak, keterampilan berbicara, keterampilan membaca, dan keterampilan menulis. Empat keterampilan berbahasa ini sangat berperan penting dalam kegiatan pembelajaran bahasa Indonesia di setiap jenjang pendidikan. Dari keempat keterampilan tersebut siswa kurang aktif untuk mengasah kemampuan mereka dalam menyusun atau menulis sebuah tulisan yang berupateks.

Dalam kurikulum 2013, mata pelajaran bahasa Indonesia harus berbasis teks dan genre. Menurut Mahsun (2014:3) teks dari genre yang dimaksudkan adalah dari sudut pandang teori semiotika sosial, teks merupakan suatu proses sosial yang berorientasi pada suatu tujuan sosial. Pembelajaran bahasa Indonesia di SMP menekankan pada pembelajaran berbasis teks. Halliday dan Ruqaiyah menyebutkan bahwa teks merupakan jalan menuju pemahaman tentang bahasa. Itu sebabnya, teks menurut mereka merupakan bahasa yang berfungsi atau bahasa yang sedang melaksanakan tugas tertentu dalam konteks situasi. Semua contoh bahasa hidup yang mengambil bagian tertentu dalam konteks situasi disebut teks. Dengan demikian, teks seperti dinyatakan Halliday dan Ruqaiyah merupakan ungkapan pernyataansuatukegiatansocialyangbersifa t verbal (Mahsun,2014:1).

Ada beragam jenisjenisteksyangdipelajariolehsiswakhususny a siswa kelas VII SMP yang salahsatuadalah teksEksplanasi. Tekseksplanasi (Explanation Text) adalahsebuahteks yangberisitentang proses-prosesyang berhubungan dengan fenomena-fenomenaalam, sosial, ilmu pengetahuan, budaya, danlainnya.Tekseksplanasi

merupakanteksyang menerangkan ataumenjelaskanmengenai proses atau fenomena, baik itu fenomena alam maupunfenomenasosial.

Berdasarkanobservasiawal peneliti dan wawancara langsungterhadapguru bahasa Indonesia di kelas VIIFSMPWisata Sanur terdapatbeberapakendala yang dihadapi dalampembelajaran Bahasa Indonesia.Kendala yang ditemukan saat menyusunteks eksplanasi yaitu sulitnya siswamenerima

pembelajarantersebutkarena

pembelajarantekseksplanasimuncul pada kurikulum baruyaitupada kurikulum 2013. Permasalahanyangjuga ditemukan yaitu siswabelummemahami dengan baik struktur tekseksplanasidan ciri--cirinya. Selain itu,dalammenyusun atau menulis 
$\begin{array}{lrr}\text { sebuahtekseksplanasipeserta } & \text { didiktidak } \\ \text { memperhatikankalimat } & \text { yang } & \text { baik } \\ \text { danbenarsehingga } & \text { hasil } & \text { tulisan } \\ \text { merekatidakmemuaskan. } & \text { Dan }\end{array}$ permasalahan yanglainnyaialah penjelasan dan bimbingankhususdari guru tidak peroleh sertametode danmedia pembelajaranyangtepatdipergunakan gurukurangmemadaidalammengembangka npembelajaran.Gurucendrungmemakaimet ode pembelajarantradisionalyakni metode ceramah. Yang membuatparasiswa merasa jenuh dan bosan dengan kegitan pembelajaran di kelas khususnya dalam kegiatan menulis sebuah teks. Seharusnya guru memperhatikan metode mengajar, agar siswa tidak merasa bosan dan mereka antusias dalam kegiatan pembelajaran di kelas.

Untuk mengatasi masalah di atas,peneliti menggunakan pembelajaran kontekstual dengan media audio-visual untuk melatih siswa dalam keterampilan menyusun teks eksplanasi. Dalam hal ini, penelitimengkolaborasikan antar pembelajaran kontekstual dengan media audio--visual supaya keberlangsungan pembelajaran di kelas menjadi efektif dan menyenangkan bagi peserta didik. Oleh karena itu, menurut peneliti dengan mengkolaborasikan antara model dengan media pembelajaran ini dapat membantu siswa untuk meningkatkan keterampilan mereka dalam menyusun tekseksplanasi.

Beberapa hasil penelitian sejenis mengenai keterampilan menyusun teks eksplanasi, diantaranya penelitian yangberjudul Keefektifan Penggunaan Model Induktif Kata Bergambar dalam pembelajaran Menulis Teks Eksplanasi pada Siswa Kelas VII SMP Negeri 1 Delanggun oleh Yuni Rahmawati”, dan penelitian berjudul "Peningkatan Keterampilan Menyusun Teks Eksplanasi dengan Model Pembelajaran Berbasis Masalah Menggunakan Video Peristiwa Alam pada Peserta Didik Kelas VII F SMPN 1Blora oleh Lela Tri Wahyuningtias." Secara umum penelitian di atas letak permasalahanya adalah mutu pembelajaran keterampilan menyusun teks eksplanasi siswa dijenjang menengah pertama masih rendah. Kondisi ini juga dialami oleh siswa kelas VII F SMP Wisata Sanur. Berdasarkan dari beberapa penelitian sebelumnya, maka peneliti melakukan sebuah penelitian yang berjudul "Peningkatan Kemampuan Menyusun Teks Eksplanasi melalui Pembelajaran Kontekstual dengan Media Audio-Visual pada Siswa Kelas VII F SMP WisataSanur."

\section{METODE PENELITIAN}

Dalam penelitian ini peneliti menggunakan jenis penelitian tindakan kelas (PTK). Menurut Sanjaya (2009:26) Penelitian Tindakan Kelas (PTK) dapat diartikan sebagai proses pengkajian masalah pembelajaran di dalam kelas melalui refleksi diri dalam upaya untuk memecahkan masalah tersebut dengan cara melakukan berbagai tindakkan yang terencana dalam situasi nyata serta menganalisis dari perlakuantersebut.

Subjek dalam penelitian ini adalah siswa-siswi kelas VII F SMP Wisata Sanur Tahun Pelajaran 2017/ 2018 yang berjumlah 42 orang siswa. Yang menjadi objek penelitian adalah peningkatan kemampuan menyusun teks eksplanasi melalui pembelajarankontekstual dengan media audio-visual. Tempat penelitian ini dilaksanakan di SMP Wisata Sanur. 
Penelitian tindakan kelas ini dilaksanakan secara bertahap atau multisiklus. Hingga dicapai hasil sesuai dengan target yang diinginkan dalam penelitian ini adalah 75. Setiap siklus akan dilaksanakan berdasarkan kolaborasi dan refleksi setelah satu tindakandilaksanakan.Analisis data dalam PTK dapat dilakukan dengan analisisi kualitatif dan analisisi kuantitatif.Analisis data kualitatif digunakan untuk menentukan peningkatan proses belajar siswa khususnya berbagai tindakan yang dilakukan guru sedangkan analisis data kuantitatif digunakan untuk menentukan peningkatan hasil belajar siswa sebagai pengaruh dari setiap tindakan yang dilakukan guru.

\section{HASIL PENELITIAN DAN PEMBAHASAN}

Pada hasil penelitian ini disajikan hasil tes menyusun teks eksplanasi siswa kelasVII F SMP Wisata Sanur tahun pelajaran 2016/2017, yang telah diperoleh peneliti selama penelitian berlangsung. Hasil tes berupa tes tertulis dalam bentuk tugas mengarang yang berhubungan dengan menyusun teks eksplanasi, terbagi atas empat bagian, yaitu : tes awal, siklus I, siklus II, dan siklus III. Hasil penelitian diuraikan sebagai berikut.Berdasarkan hasil tes awal maka dapat dideskripsikanhal-halsebagai berikut.

1. Mengamati proses pembelajaran yang sedang berlangsung untuk mengetahui hambatan--hambatan atau kelemahan-- kelemahan yang terjadi pada proses pembelajaran menyusun tekseksplanasi.
2. Mengadakan tes awal untuk mengetahui kemampuan dasar siswa di dalam menyusun tekseksplanasi.

Pada tahap observasi awal, peneliti melakukan pengamatan terhadap sikap siswa selama mengikuti proses pembelajaran menyusun teks eksplanasi. Hasil observasi pada awal pertemuan pada hari Selasa, 29 Maret 2018 ialah sebagai berikut. (a) Saat proses pembelajaran sedang berlangsung siswa hanya mendengarkan penjelasan guru, karena metode pembelajaran yang digunakan adalah metode ceramah. Tidak banyak siswa yang mampu menjawabpertanyaan.(b) Siswa kurang memahami materi tentang menyusun teks eksplanasi. (c) Siswa tidak begitu antusias dalam menerima pelajaran khususnya mengenai menyusun teks eksplanasi. (d) Siswa belum mampu menyusun teks eksplanasi.

Kegiatan tes awal di laksanakan pada hari Selasa, 29 Maret 2018. Kegiatan dengan penyampain tujuan penelitian dan kegiatan yang akan dilakukan selama penelitian berlangsung, setelah itu siswadiberikan contoh teks eksplanasi yang telah disiapkan oleh peneliti. Selanjutnya siswa menyusun teks eksplanasi mengenai proses terjadinya gempa bumi. Dari hasil tes awal peningkatan kemampuan menyusun teks eksplanasidi atas menunjukkan kemampuan siswa masih kurang. Dilihat dari nilai rata-rata siswa 4,07. Rincian data tersebut dijelaskan bahwa 25 orang siswa mendapat skor standar 4 dengan $59,52 \%, 8$ orang siswa 
mendapatskorstandar 3 dengan $19,04 \%, 7$ orang siswa mendapat skor standar 5 dengan $16,66 \%$, dan 2 orang siswa mendapat skor standar 6 dengan $4,76 \%$.

Pada tahap perencanaan siklus I ini dilakukan pelaksanaan pembelajaran menyusun teks eksplanasi. Langkah-- langkah yang dilakukan adalah sebagai berikut: (1) Menyusun Rencana Pelaksanaan Pembelajaran (RPP) mengenai menyusun teks eksplanasi kelas VII F sesuai Pembelajaran Kontekstual dengan media audio-visual; (2) Peneliti mempersiapkan bahan pelajaran, yaitu materi menyusun teks eksplanasi, dan sebuah contoh teks eksplanasi yang berjudul "Gempa Bumi”;(3) Mempersiapkan media pembelajaran yaitu laptop, LCD dan alat tulis; dan (4) Membuat lembar observasi dan juga tes tulis dalam bentuk tugas mengarang tentang menyusun teks eksplanasi mengenai peristiwa alam yang berjudul "Tsunami" dan membuat lembar format penilaian siswa.

Pada tahap ini dilakukan tindakan sesuai dengan Rencana Pelaksanaan Pembelajaran yang telah disusun. Pembelajaran yang dilakukan adalah pembelajaran menyusun teks eksplanasi melalui penerapan pembelajaran kontekstual dengan media audio-visual. Pelaksanaan tindakan siklus I dilakukan sebanyak 1 kali pertemuan (2x40 menit), yaitu pada hari Rabu, 30 Maret 2018.

Hasil tes Siklus I menunjukkan bahwa sebagian besar siswa mempunyai kemampuan menyusun teks eksplanasi dengan kategori "Hampir Cukup". Hal ini terlihat pada rata--rata nilai yang mencapai 5,30 dan termasuk kategori "Hampir Cukup". Rincian data tersebut sebagai berikut. Sebanyak 2 orang memperoleh nilai 7 dengan kategori lebih dari cukup dengan 4,76\%, sebanyak 12 orang siswa memperoleh nilai 6 dengan kategori cukup 28,57\% , sebanyak 25 orang siswa memperoleh nilai 5 dengan kategori hampir cukup $59,52 \%$. Sebanyak 3 orang siswa memperoleh nilai 4 dengan kategori kurang $7,14 \%$. Berdasarkan nilai rata-rata di atas, maka kemampuan menyusun teks eksplanasi pada siswa kelas VII F SMP Wisata Sanur Tahun Pelajaran 2017/ 2018 telah mengalami peningkatan dibandingkan sebelum penerapan pembelajaran kontekstual dengan media audio--visual, tetapi secara keseluruhan siswa belum mencapai nilai KKM75.

Peneliti melakukan refleksi pada hasilyang didapat pada saat melakukan observasi dan evaluasi siklus I. Berdasarkan pada analisis data di atas, dapat digambarkan bahwa 42 orang siswa kelas VII F SMP Wisata Sanur Tahun Pelajaran 2017/ 2018, telah mengikuti pembelajaran menyusun teks eksplanasi melalui pembelajaran kontekstual dengan media audio-visual siklus I. Hasil yang diperoleh dari pelaksanaan tindakan pada siklusI, baik berdasarkan hasil observasi maupun hasil tes maka perlu dilakukanperencanaanpelaksanaan tindakan siklus berikutnya atau siklusII.

Pelakasanaan pembelajaran 
Siklus II dilakasanakan satu kali pertemuan, yaitu pada hari Jumat 1 April 2018. Pekaksanasiklus II dilakukan karena pembeljaran pada siklus I siswa belum mampu menerapkan pembelajaran kontekstual dengan media adio-visual dengan baik,sehingga belum berhasil mengatasi masalah-masalah dalam menyusun teks eksplanasi.

Berlangsungnya

proses

pembelajaran melalui pembelajaran kontekstual dengan media audio-visual pada siklus II sudah mengalami peningkatan, dilihat dari keberanian siswa untuk bertanya mengenai hal yang belum mengerti sehingga banyak siswa yang memperoleh nilai baik. Walaupun ada penigkatan pada siklus II tetapi masih ada beberapa siswa yang mendapat nilai kurang dalam menyusun teks eksplanasi melalui pembelajaran kontekstual dengan media audio-visual.Maka dari itu, peneliti perlumelanjutkan pembelajaran ke siklus selanjutnya.

Berdasarkan hasil tes siklus II dapat diketahui bahwa skor standar yang diperoleh siswa sejumlah 291 dengan nilai rata-rata 6,92 yang diklelompokkan dengan kategori lebih dari cukup. Nilai rata-rata siklus II ini menunjukkan adanya peningkatan dibandingkan dengan nilai rata--rata pada siklus I. Rincian data tersebut adalah sebagai berikut. Sebanyak 1 orang siswa memperoleh nilai 9 dengan kategori baik sekali dengan $2,38 \%$

sebanyak6orangsiswamemperolehnilai

8 dengan kategori baik dengan $14,28 \%$, sebanyak 24 orang siswa memperolehnilai7 dengan kategori lebih dari cukup 57,14\%, sebanyak 11 orang siswa memperoleh nilai 6 dengan kategori cukup dengan $26,19 \%$. Berdasarkan nilai rata- rata siklus II di atas, maka kemampuan menyusun teks eksplanasi siswa kelas VII F SMP Wisata Sanur Tahun Pelajaran 2017/ 2018 telah mengalami peningkatandibandingkan nilai rata--rata siklus I, tetapi secara keseluruhan siswa belum mencapai nilai KKM 75.

Sesuai dengan perencanaan yang telah disusun, maka pelaksanaan tindakan siklus III dilaksanakan sebanyak 1 kali pertemuan (2x 40 menit), yaitu pada hari Selasa, 5 April 2018. Pelaksanaan siklus III dilakukan karena siswa masih malu- malu dalam mempresetasikan hasil pekerjaan mereka. Namum mereka telah menerapkan pembelajaran kontekstual dengan media audio-visual.Pada Siklus ini peneliti memberikan bimbingan kepada siswa yang mengalami kesulitan dalam menyusun tekseksplanasi.

Hasil tes siklus III menunjukkan bahwa sebagian besar siswa mempunyai kemampuan menyusun teks eksplanasi dengan kategori "Baik Sekali”.Hal ini terlihat pada rata-rata nilai seluruh siswa yang mencapai 8.40 dan termasuk kategori "Baik Sekali”. Rincian data tersebut ialah sebagai berikut: dari jumlah keseluruhan siswa yaitu 42 orang. Sebanyak 2 orang siswa yang memperoleh nilai 10 dengan kategori istimewa $4,76 \%$, sebanyak 13 orang siswa memperoleh nilai 9 dengan 
kategori baik sekali 30,95\%, sebanyak 27 orang siswa memperoleh nilai 8 dengan kategori baik 64,28\%. Berdasarkan nilai rata-rata siklus III di atas, maka kemampuan menyusun teks eksplanasi siswa kelas VII F SMP Wisata Sanur Tahun Pelajaran 2017/ 2018 telah mengalami peningkatan dibandingkan dengan nilai rata-rata siklus II dan secara keseluruhan siswa telah melampaui nilai KKM 75.

Melalui penelitian ini diperoleh gambaran bahwa terjadi peningkatan kemampuan menyusun teks eksplanasi melalui pembelajaran Kontekstual dengan media Audio-Visual pada siswa kelas VII FSMP Wisata Sanur Tahun Pelajaran 2017/2018. Peningkatan ini dapat dilihat dari hasil nilai yang diperoleh siswa dalam setiap siklus, nilai rata--rata siklus III yaitu 8,40 hasilnya lebih baik dibandingkan nilai rata--rata siklus II yaitu 6,92 dan nilai rata- rata siklus I yaitu 5,30 serta nilai rata--rata tes awal yang hanya mencapai 4,07. Peningkatan kemampuan siswa menyusun teks eksplanasi terjadi karena telah diterapkannya model pembelajaran dengan media pembelajaran dan juga perbaikan langkah-langkah atau modifikasi tindakan dalam setiap siklus. Berdasarkan hasil observasi yang dilakukan peneliti terhadap siswa selama proses pembelajaran berlangsung menunjukkan peningkatan aktivitas siswa yaitu: (1) Semua siswa mengikuti kegiatan belajar mengajar dengan tekun dan sungguh-sungguh, (2) Semua siswa terlibat dalam memahami materi pelajaran, (3) Terjadi peningkatan keaktivan siswa dalam mengemukakan pendapat, komentar dan pertanyaan.

Adapun langkah--langkah pembelajaran yang tepat diterapkan oleh guru untuk peningkatkan kemampauan menyusun teks eksplanasi melalui pembelajaran kontekstual dengan media audi-visual adalah sebagai berikut.

1. Persiapan

Dalam tahap ini guru mempersiapkan rancangan pelajaran dengan membuat Skenario Pembelajaran (SP), Lembar Kerja Siswa (LKS) yang sesuai dengan pembelajaran Kontekstual dengan Media AudioVisual.

2. Mengarahkan

Guru mengarakan siswa untuk memulai kegiatan pembelajaran menyusun tekseksplanasi.

3. Mendemontrasikan

Guru mendemontrasikan ilustrasi gambaran materi dengan media audio-visual. Guru menyuguhkan video mengenai peristiwa alam yang sesuai dengan kemampuan siswa dalam menyusun tekseksplanasi.

4. Mengamati

Siswa mengamati video peristiwa alam dengan cermat agar informasi yang disampaikan dari tayangan video tersebut terdengar dengan jelas.

5. MengumpulkanBahan

Setelah menonton tayangan video mengenai peristiwa alam siswa mengumpulkan bahan untuk 
menyusun teks eksplanasi sesuai dengan video yang ditayangkan dan mengidentifikasi bahan--bahan yang digunakan untuk menulis teks eksplanasi.

6. Menyusun

Setelah mengumpulkan bahan siswa meyusun teks eksplanasi berdasarkan video yang ditayangkan.

7. Mempresentasikan

Siswa mempresentasikan tulisan tentang teks eksplanasi dengan penuh rasa percaya diri dan bahasa yang lugas.

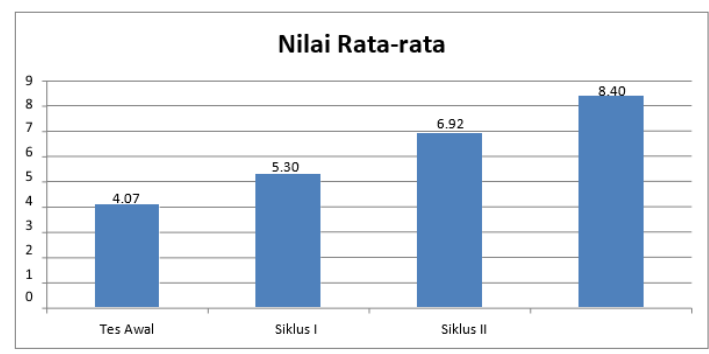

Grafik 01. Peningkatan Kemampuan Menyusun Teks Eksplanasi melalui Pembelajaran Kontekstual dengan Media Audio-Visual pada Siswa Kelas VII F SMP Wisata Sanur Tahun Pelajaran 2017/ 2018 Pada Tes Awal, Siklus I, Siklus II dan SiklusIII.

Pada grafik 01 di atas ditunjukkan bahwa terjadi peningkatan hasil belajar menyusun teks eksplanasi melalui pembelajaran Kontekstual dengan Media Audio-Visual pada siswa kelas VII F SMP Wisata Sanur Tahun Pelajaran 2017/2018 dari setiap siklusnya. Pada tes awal atau pra tes nilai rata--rata siswa adalah 4,07, mengalami peningkatan pada siklus I dengan nilai rata--rata 5,30 mengalami peningkatan lagi pada siklus II dengan nilai rata--rata 6,92 dan pada
siklusIIIjuga mengalami peningkatan dengan nilai rata--rata 8,40. Peningkatan terjadi tidak lepas dari revisi atau modifikasi tindakan yang dilakukan peneliti pada setiap siklusnya.Dengan demikian perencanaan pembelajaran kontekstual dengan media audio-visual dalam pembelajaran sangat baik dalam upaya peningkatan kemampuanmenyusun teks eksplanasi.Oleh karena itu, penelitian ini dihentikan pada siklus III.

\section{SIMPULAN}

Berdasarkan hasil analisis data pada bab IV dapat disimpulkan bahwa melalui pembelajaran Kontekstual dengan Media Audio-Visualdapat meningkatkan kemampuan menyusun teks eksplanasi pada siswa kelas VII F SMP Wisata Sanur Tahun Pelajaran 2017/ 2018 hal ini terbukti dari hasil penelitian sebagai berikut.

\section{Yangpertama,}

Penerapanpembelajarankontekstual dengan media Audio-Visual tesawaluntuk meningkatkan kemampuan menyusun teks eksplanasi. Jumlah keseluruhan siswa yaitu 42 orang, siswa yang diteliti memperoleh nilai rata-rata sebesar 4,07 termasuk kategori "kurang". Pada siklus I dari 42 orang siswa yang diteliti, menunjukkan bahwa sebagian besar siswa mempunyai kemampuan menyusun teks eksplanasi dengan kategori "Hampir Cukup". Hal ini terlihat pada rata-rata nilai yang mencapai 5,30.SiklusII menunjukkan bahwa sebagian besar siswa mempunyai kemampuan menyusun teks eksplanasi dengan kategori "Lebih dari Cukup". Hal ini terlihat pada rata-rata nilai seluruh siswa yang mencapai 6,92, dan siklus III menunjukkan bahwa 
sebagian besar siswa mempunyai kemampuan menyusun teks eksplanasi dengan kategori "Baik Sekali". Hal ini terlihat pada rata-rata nilai seluruh siswa yang mencapai 8,40. Oleh karena itu, penelitian tindakan kelas ini dihentikan pada siklus III.Pada siklus III mengalami peningkatan yang signifikan dari siklus II, siklus I, dan tes awal.Yang Kedua, adapun langkah--langkah pembelajaran yang tepat diterapkan oleh guru untuk peningkatkan kemampauan menyusun teks eksplanasi melalui pembelajaran kontekstual dengan media audi--visual adalah sebagai berikut.(1) Persiapan. Dalam tahap ini guru mempersiapkan rancangan pelajaran dengan membuat Skenario Pembelajaran (SP), Lembar Kerja Siswa (LKS) yang sesuai dengan pembelajaran kontekstual dengan media audio-visual. (2) Mengarahkan. Guru mengarahkansiswauntuk memulai kegiatanpembelajaran menyusunteks eksplanasi. (3) Mendemontrasikan.Guru mendemontrasikanilustrasi gambaran materi dengan media audio-visual. Guru menyuguhkan video mengenai peristiwa alam yang sesuai dengan kemampuan siswa dalam menyusun teks eksplanasi. (4)Mengamati.Siswa mengamati video peristiwaalam dengan cermat agar informasi yang disampaikan dari tayangan video tersebut terdengar dengan jelas. (5) Mengumpulkan Bahan. Setelah menonton tayangan video mengenai peristiwa alam siswamengumpulkan bahanuntuk menyusuntekseksplanasi sesuai dengan video yang ditayangkan dan mengidentifikasi bahan-bahan yang akan diguakan untuk menulis tekseksplanasi.(6) MenyusunTeks Eksplanasi. Setelahmengumpulkan bahan siswa meyusun teks eksplanasi berdasarkan video yang diayangkan.(7) Mempresentasikan.Siswa mempresentasikantulisan tentangteks eksplanasi dengan penuh rasa percaya diri dan bahasa yanglugas.

\section{SARAN}

Berdasakan hasil penelitian yang dilakukan tentang menyusun teks eksplanasi melaluipenerapan pembelajaran kontekstual dengan media audio--visual pada siswa kelas VII F SMP Wisata Sanur Tahun Pelajaran 2017/ 2018, maka penulis memberikan beberapa saran yang dapat digunakan sebagai tindak lanjut hasil penelitian ini, yaitu : (1) Guru dalam memberikan pelajaran hendaknya memilih metode dan media pembelajaran yang bervariasi, agar siswa tidak jenuh dengan metode pembelajaran yang monoton.(2) Dalam kegiatan pembelajaran khusus mengenai menyusunteks eksplanasi, guru hendaknya lebih sering memberikancontoh-contoh teks eksplanasi agar dapat dipergunakan sebagai acuan sehingga pengetahuan siswa lebih luas terkait materi yangdisampaikan.(3) Pembelajaran Kontekstual dengan Media Audio-Visual diketahui dapat meningkatkan kemampuan dan minat siswa dalam materi menyusun teks eksplanasi. Oleh karena itu, guru dapat mempergunakan metode dan media tersebut dalam pembelajaran di kelas. (4) Siswa hendaknya lebih aktif dan kreatif dalam menerima pelajaran, sehinggapembelajaran dapat berlangsung dengan baik dan efektif. 


\section{DAFTAR PUSTAKA}

http://variansmakalah.blogspot.co.id/2015/ 06/media-audio-visual.html. diunduh: pada tanggal02 Maret2016.

Komalasari, Kokom. 2010. Pembelajaran Kontekstual; Konsep dan Aplikasi. Bandung: Refika Aditama.

Mahsun. 2014. Teks dalam Pembelajaran Bahasa Indonesia Kurikulum 2013. Jakarta: PT Raja GrafindoPersada.

Nurkencana, 1990. Metodologi Penelitian.Jakarta: PT Bina Aksara.

Nurkencana, W dan P.P.N. Sumartana, 1981. Evaluasi Pendidikan. Surbaya: Usaha Nasional.

Sanjaya, Wina.2009. Penelitian Tindakan Kelas. Bandung: Kencana.

Rahmawati, Yuni. 2015. "Keefektifan Penggunaan Model Induktif

Kata Bergambar Dalam Pembelajaran Menulis Teks Eksplanasi Pada Siswa Kelas VII SMP Negeri 1 Delanggun Klaten". Universitas Negeri Yoyakarta. http://eprints.uny.ac.id/23962/1/S KRIPSI.pdf. diunduh pada tanggal 26 Oktober 2015.

Tarigan, Henry Guntur. 2008. Menulis Sebagai Suatu Keterampilan Berbahasa. Bandung: Angkasa.

Wahyuningtias, Lela Tri. 2015. "Peningkatan Keterampilan Menyusun Teks Eksplanasi Dengan Model Pembelajaran Berbasis Masalah Menggunakan Video Peristiwa Alam Pada Peserta Didik Kelas VII F SMP N 1 Blora". Universitas Negeri Semarang. Semarang. http://lib.unnes.ac.id/22206/1/210 1411019-s.pdf. diunduh pada tanggal 8 Januari 2016 